\title{
Anthelmintic activity of nanoencapsulated carvacryl acetate against gastrointestinal nematodes of sheep and its toxicity in rodents
}

\author{
Atividade anti-helmíntica do acetato de carvacrila nanoencapsulado \\ sobre nematoides gastrintestinais de ovinos e toxicidade em roedores
}

Weibson Paz Pinheiro André1, José Ribamar de Paiva Junior², Géssica Soares Cavalcante ${ }^{1,3}$, Wesley Lyeverton Correia Ribeiro ${ }^{4}$, José Vilemar de Araújo Filho ${ }^{1}$, Jéssica Maria Leite dos Santos ${ }^{5}$, Ana Paula Negreiros Nunes Alves ${ }^{6}$, Jomar Patrício Monteiro ${ }^{7}$, Selene Maia de Morais ${ }^{3}$, Isaac Neto Goes da Silva ${ }^{8}$, Lorena Mayana Beserra de Oliveira', Flávia Oliveira Monteiro da Silva Abreu², Claudia Maria Leal Bevilaqua1* (D)

\footnotetext{
${ }^{1}$ Laboratório de Doenças Parasitárias, Programa de Pós-graduação em Ciências Veterinárias, Universidade Estadual do Ceará - UECE, Fortaleza, CE, Brasil

${ }^{2}$ Laboratório de Química Analítica e Ambiental, Programa de Pós-graduação em Ciências Naturais, Universidade Estadual do Ceará - UECE, Fortaleza, CE, Brasil

${ }^{3}$ Laboratório de Química de Produtos Naturais, Programa de Pós-graduação em Ciências Veterinárias, Universidade Estadual do Ceará - UECE, Fortaleza, CE, Brasil

${ }^{4}$ Departamento de Fisiologia e Farmacologia, Faculdade de Medicina, Universidade Federal do Ceará - UFC, Fortaleza, CE, Brasil

${ }^{5}$ Centro Universitário INTA - UNINTA, Sobral, CE, Brasil

${ }^{6}$ Faculdade de Farmácia, Odontologia e Enfermagem, Universidade Federal do Ceará - UFC, Fortaleza, CE, Brasil

${ }^{7}$ Embrapa Caprinos e Ovinos, Sobral, CE, Brasil

${ }^{8}$ Laboratório de Patologia Clínica, Faculdade de Veterinária, Universidade Estadual do Ceará - UECE, Fortaleza, CE, Brasil
}

How to cite: André WPP, Paiva Junior JR, Cavalcante GS, Ribeiro WLC, Araújo Filho JV, Santos JML, Alves APNN, Monteiro JP, Morais SM, Silva ING, Oliveira LMB, Abreu FOMS, Bevilaqua CML. Anthelmintic activity of nanoencapsulated carvacryl acetate against gastrointestinal nematodes of sheep and its toxicity in rodents. Braz J Vet Parasitol 2020; 29(1): e013119. https://doi.org/10.1590/S1984-29612019098

\begin{abstract}
The objective of this study was to evaluate the efficacy of carvacryl acetate (CVA) and nanoencapsulated CVA (nCVA) on gastrointestinal nematodes of sheep. The CVA was nanoencapsulated with chitosan/gum arabic and the efficacy of nanoencapsulation (EE), yield, zeta potential, nanoparticle morphology and release kinetics at $\mathrm{pH} 3$ and 8 were analyzed. Acute and subchronic toxicity were evaluated in rodents and reduction of egg counts in the faeces (FECRT) of sheep. The sheep were divided into four groups ( $n=10): \mathrm{G1}, 250 \mathrm{mg} / \mathrm{kg} \mathrm{CVA} ; \mathrm{G} 2,250 \mathrm{mg} / \mathrm{kg} \mathrm{nCVA} ; \mathrm{G3}$, polymer matrix and G4: $2.5 \mathrm{mg} / \mathrm{kg}$ monepantel. EE and nCVA yield were $65 \%$ and $57 \%$, respectively. The morphology of the nanoparticles was spherical, size $(810.6 \pm 286.7 \mathrm{~nm})$, zeta potential in pH 3.2 $(+18.3 \mathrm{mV})$ and the $50 \%$ release of CVA at pHs 3 and 8 occurred at 200 and $10 \mathrm{~h}$, respectively. nCVA showed $\mathrm{LD}_{50}$ of $2,609 \mathrm{mg} / \mathrm{kg}$. CVA, nCVA and monepantel reduced the number of eggs per gram of faeces (epg) by $57.7 \%, 51.1 \%$ and $97.7 \%$, respectively. The epg of sheep treated with CVA and nCVA did not differ from the negative control $(P>0.05)$. Nanoencapsulation reduced the toxicity of CVA; however, nCVA and CVA presented similar results in the FECRT.
\end{abstract}

Keywords: Chitosan, gum arabic, biocompounds, acetylation, toxicological safety, Haemonchus contortus.

\section{Resumo}

O objetivo deste trabalho foi avaliar a eficácia do acetato de carvacrila (ACV) e do ACV nanoencapsulado (nACV) sobre nematóides gastrintestinais de ovinos. O ACV foi nanoencapsulado com quitosana/goma arábica e foi analisada a eficácia de nanoencapsulamento (EE), o rendimento, 
potencial zeta, morfologia das nanopartículas e cinética de liberação em pH 3 e 8. Foram avaliadas as toxicidades aguda e subcrônica em roedores e a redução da contagem de ovos nas fezes (RCOF) de ovinos. Os ovinos foram divididos em quatro grupos ( $\mathrm{n}=10$ ): G1, $250 \mathrm{mg} / \mathrm{kg} \mathrm{ACV;} \mathrm{G2,} 250 \mathrm{mg} / \mathrm{kg}$ de $\mathrm{nACV} ; \mathrm{G} 3$, matriz polimérica e G4: 2,5 mg/kg de monepantel. A EE e o rendimento de $\mathrm{nACV}$ foram de $65 \%$ e 57\%, respectivamente. A morfologia das nanopartículas foi esférica, tamanho $(810,6 \pm 286,7 \mathrm{~nm})$, potencial zeta no $\mathrm{pH} 3,2(+18,3 \mathrm{mV})$ e a liberação de $50 \%$ de CVA nos $\mathrm{pHs} 3$ e 8 ocorreu às 200 e $10 \mathrm{~h}$, respectivamente. nACV apresentou $\mathrm{DL}_{50}$ de $2.609 \mathrm{mg} / \mathrm{kg}$. ACV, nACV e o monepantel reduziram a contagem de ovos por grama de fezes (opg) em 57,7\%, 51,1\% e 97,7\%, respectivamente. A contagem de opg de ovelhas tratadas com ACV e nCVA não diferiu do controle negativo $(P>0,05)$. O nanoencapsulamento reduziu a toxicidade do AVC; no entanto, nACV e ACV apresentaram resultados semelhantes na RCOF.

Palavras-chave: Quitosana, goma arábica, biocompostos, acetilação, segurança toxicológica, Haemonchus contortus.

\section{Introduction}

Gastrointestinal nematode parasitism, especially Haemonchus contortus, is one of the main limiting factors of small ruminant production worldwide because it endangers the health, welfare and productivity of sheep and goats (Araújo-Filho et al., 2018; Elmahalawy et al., 2018). The control of these nematodes is performed with the administration of anthelmintics. However, the continuous use of these drugs has inevitably led to the development of resistant and/or multiresistant nematode populations worldwide (Kotze \& Prichard, 2016; Santos et al., 2017), including in northeastern Brazil (Silva et al., 2018).

New alternatives for the control of gastrointestinal nematodes are being studied, with an emphasis on plant bioactives and their isolated compounds (Kearney et al., 2016). Essential oils are complex mixtures of volatile constituents produced by aromatic plants that present several biological activities, mainly anthelmintic activity (Macedo et al., 2010; Raut \& Karuppayil, 2014).

Carvacrol is a phenolic compound found mainly in essential oils of plants of the family Lamiaceae (Besier et al., 2016) and has antiparasitic activity (Zhu et al., 2013; Shang et al., 2016; Fabbri et al., 2016). This monoterpene presents high toxicity, and acetylation is an alternative that potentiates its biological activity and increases its toxicological safety (Morais et al., 2014; Andre et al., 2016). Carvacryl acetate (CVA) showed anthelmintic activity against Schistosoma mansoni (Moraes et al., 2013), $H$. contortus and other sheep gastrointestinal nematodes in in vitro and in vivo assays, but the efficacy did not reach the desired therapeutic level (Andre et al., 2016).

The nanoencapsulation of bioactive compounds has been used as an alternative to protect drugs and promote a sustained release in animals, increasing bioavailability and maximizing the nematicidal effect (Zhao et al., 2010; Ribeiro et al., 2014; Ribeiro et al., 2017). The polyelectrolyte complex is a technique used for the nanoencapsulation of bioactive compounds by mixing oppositely charged polymers in solutions (Minkal et al., 2018). Among these polymers, we highlight chitosan, a polysaccharide that is obtained by the deacetylation of chitin. This biopolymer presents properties such as biocompatibility, biodegradability and nontoxicity and is used in pharmaceutical applications for controlled drug release (Shariatinia \& Mazloom-Jalali, 2019). The positively charged amino groups of chitosan react with an anionic group of polysaccharides, such as gum arabic, leading to the formation of a polyelectrolyte complex (Tan et al., 2016; Minkal et al., 2018). Gum arabic is a biopolymer obtained from Acacia senegal or Acacia seyal and is widely used in the food and pharmaceutical industries (Guan \& Zhong, 2015; Sanchez et al., 2018).

Thus, the aim of this study was to evaluate the anthelmintic activity of CVA and nCVA against gastrointestinal nematodes of sheep and the toxicity of CVA and nCVA in rodents. 


\section{Materials and Methods}

\section{Carvacrol acetylation}

A solution containing $1 \mathrm{~g}$ of carvacrol (purity $\geq 98 \%$; Sigma-Aldrich ${ }^{\circledR}$, St. Louis, USA), $15 \mathrm{~mL}$ of acetic anhydride P.A. (Dinâmica ${ }^{\circledR}$, São Paulo, Brazil) and $1.5 \mathrm{~g}$ of sodium acetate P.A. (Dinâmica ${ }^{\circledR}$, São Paulo, Brazil) was refluxed for $1 \mathrm{~h}$ at room temperature. Cold water was added $(20 \mathrm{~mL})$, and the solution was neutralized to $\mathrm{pH} 7.0$ with $5 \%$ sodium bicarbonate P.A. (Dinâmica ${ }^{\circledR}$, São Paulo, Brazil). The solution was transferred to a separating funnel and washed three times with chloroform P.A. (100 mL) (Dinâmica ${ }^{\circledR}$, São Paulo, Brazil). The chloroform phase, containing the acetylated material, was washed with water and dried with sodium sulfate P.A. (Dinâmica ${ }^{\circledR}$, São Paulo, Brazil). The solvent was rotoevaporated (Matos, 1997). CVA was subjected to thin layer chromatography and characterized by gas chromatography mass spectrometry (GC-MS). The yield of CVA was $83 \%$.

\section{GC- MS analysis}

The chemical analysis of CVA was performed with a Shimadzu QP-2010 Ultra instrument employing the following conditions: column: Rtx-5MS (Crossbond 5\%, diphenyl/95\% dimethyl polysiloxane) with $30 \mathrm{~m} \times 0.25 \mathrm{~mm} \times 0.25 \mu \mathrm{m}$ df; carrier gas: $\mathrm{He}(24.2 \mathrm{~mL} / \mathrm{min}$, in constant linear velocity mode); mass spectra: electron impact $70 \mathrm{eV}$; injector temperature: $250{ }^{\circ} \mathrm{C}$ in split mode $(1: 100)$; detector temperature: $250^{\circ} \mathrm{C}$; and the column temperature was programmed $35-180^{\circ} \mathrm{C}$ at $4^{\circ} \mathrm{C} / \mathrm{min}, 180-280^{\circ} \mathrm{C}$ at $17^{\circ} \mathrm{C} / \mathrm{min}$ and at $280^{\circ} \mathrm{C}$ for $10 \mathrm{~min}$. Compounds were identified by their retention times relative in $\mathrm{GC}$ to known compounds and by comparison of their mass spectra with those present in the computer data bank (NIST) and published literature (Adams, 2007).

\section{Nanoencapsulation of carvacryl acetate}

The nanoparticles were produced from a polyelectrolytic complexation system according to Abreu et al. (2008). The chitosan (Polymar ${ }^{\circledR}$, Ceará, Brazil) were purified as described by Abreu et al. (2013), with a viscosity molar mass (Mz) $41.26 \times 10^{4} \mathrm{~g} / \mathrm{mol}$ and $72 \%$ degree of deacetylation. A solution of $1 \%$ chitosan and Tween 80 was subjected to mechanical stirring. Subsequently, $300 \mu \mathrm{L}$ of CVA was added to the solution and submitted to an ultrasonic bath (Ultra 800, Ciencor Scientific Ltd., São Paulo, Brazil) for 15 min. For formation of the prenucleus of the nanoparticles, $0.1 \%$ sodium tripolyphosphate P.A. (STP) (Dinâmica ${ }^{\circledR}$, São Paulo, Brazil) was added dropwise at the chitosan:STP ratio of 50:1, and the solution was subjected to magnetic stirring for $30 \mathrm{~min}$. Then, $1 \%$ gum arabic $(\mathrm{w} / \mathrm{v})$ (Dinâmica ${ }^{\circledR}$, São Paulo, Brazil) was added to the solution at a chitosan:gum arabic ratio of $10: 1$, and then the solution was subjected to magnetic stirring for another $30 \mathrm{~min}$. For the production of particles in bilayers, the monolayer particles were suspended in $20 \mathrm{~mL}$ of distilled water and subjected to magnetic stirring. Chitosan (1\%) was added dropwise and was stirred continuously for an additional $30 \mathrm{~min}$. Subsequently, $1 \%$ gum arabic (w/v) was added and stirred continuously for an additional $30 \mathrm{~min}$. The solution was centrifuged at 4,000 rpm for $20 \mathrm{~min}$, the supernatant was removed and the bilayer nanoparticles were subjected to the lyophilization process.

\section{Encapsulation efficiency}

The encapsulation efficiency (EE) of CVA was determined by absorption spectroscopy with a Genesys $10 \mathrm{~S}$ UV-Vis (Thermo Scientific, Massachusetts, USA) at a wavelength of $271 \mathrm{~nm}$. A solution of $10 \mathrm{~mL}$ of $95 \%$ ethanol with $10 \mathrm{mg}$ of nanoparticles was stirred constantly for $48 \mathrm{~h}$, and the concentration of CVA was determined according to the 
calibration curve using equation 1, with the absorbance (abs) and the CVA concentration (conc) in $\mathrm{mg} / \mathrm{mL}$.

$a b s=0.0028 c o n c-0.0368 ; R^{2}=0.994$

\section{Physicochemical characterization of nanoparticles}

nCVA was characterized by Fourier transform infrared spectroscopy (FTIR) using a Nicolet is5 spectrophotometer (Thermo Scientific). The samples were prepared as potassium bromide pellets $(\mathrm{KBr})$ at a ratio of 1:20 $(\mathrm{m} / \mathrm{m})$ (sample: $\mathrm{KBr})$. The morphology of the nanoparticles was evaluated with scanning electron microscopy (Quanta FEG 450 Electronic Microscope, environmental FEI). The samples were fixed on carbon strips, dried in a desiccator and covered with a thin layer of gold, using a $20 \mathrm{kV}$ acceleration voltage.

Particle size, surface charge at different $\mathrm{pH}$ values (3 - 8) and the point of zero charge was determined through zeta potential measurements using a Nano ZetaSizer analyzer (Malvern 3600, Worcestershire, UK) using a laser wavelength of $632.8 \mathrm{~nm}$ and a fixed dispersion angle of $173^{\circ}$.

\section{Release kinetics}

The kinetics of nCVA release were obtained using a dialysis system. The sample (60 $\mathrm{mg}$ nanoparticles) was introduced into cellulose acetate membranes (14 KDa pores) and dialyzed against $60 \mathrm{~mL}$ of $0.001 \mathrm{M} \mathrm{HCL}(\mathrm{pH}$ 3) or borate buffer $(\mathrm{pH} 8)$ solution and 1\% (v/v) Tween 80. Three aliquots were taken at regular time intervals and analyzed by spectrophotometry in Genesys 10S UV-vis (Thermo Fisher Scientific, USA). Thus, the concentration of CVA present in the medium was calculated using a calibration curve and equation 1.

The mechanisms of release of CVA from the nanoparticles were evaluated using the zero order, first order, Higuchi, Hixson-Crowell, and Korsmeyer-Peppas mathematical models (Costa, 2002). Linear regression was used to calculate the values of the release constants ( $k$ ) and the correlation coefficients ( $r$ ).

\section{Ethics committee on animal welfare}

This study was approved by the Ethics Committee of the Universidade Estadual do Ceará (Protocol Number: 6511846/2016).

\section{Acute toxicity}

Acute toxicity was performed according to OECD (2008a) (Up-and-down procedure). Female Swiss mice ( $\mathrm{n}=12$ ) weighing $28.4 \pm 2.5 \mathrm{~g}$ were allowed to acclimatize to the laboratory conditions (luminosity: $12 \mathrm{~h} / 12 \mathrm{~h}$, light/dark; temperature: $22 \pm 2{ }^{\circ} \mathrm{C}$; relative humidity: $60 \%$ ) for seven days and were provided commercial feed (Labina ${ }^{\circledR}$, Purina, São Paulo, Brazil) and water ad libitum. The animals were divided into 2 groups and received the following treatments: $\mathrm{G} 1(\mathrm{n}=8), \mathrm{nCVA}$ at doses of $175,440,1,110$ and $2,800 \mathrm{mg} / \mathrm{kg}$ and $\mathrm{G} 2(\mathrm{n}=3)$, polymer matrix (negative control). The dose correction factor was 3.2-fold, and dose increase or reduction was performed according to the survival or mortality of the animals, respectively. Each animal was carefully evaluated for up to $48 \mathrm{~h}$ prior to the decision of the dose to be administered to the next animal. The dosage was discontinued when five reversals occurred in six consecutive nCVA-treated animals. All decisions regarding the doses administered and the estimation of the lethal dose for $50 \%\left(L_{50}\right)$ were performed using the AOT425StatPgm software. 


\section{Subchronic toxicity in rats}

Subchronic toxicity was performed according to OECD (2008b). Female Wistar albino rats $(n=24)$ weighing $159.8 \pm 11.9 \mathrm{~g}$ were allowed to acclimatize to the laboratory conditions for seven days and were provided commercial feed (Labina ${ }^{\circledR}$, Purina, São Paulo, Brazil) and potable water ad libitum. The animals were randomly divided into 3 groups $(n=8)$ and received the following treatments: G1: $250 \mathrm{mg} / \mathrm{kg}$ CVA; G2: $250 \mathrm{mg} / \mathrm{kg} \mathrm{nCVA}$; and G3: polymer matrix (negative control). The treatments were administered daily by gavage for 28 days. Toxic manifestations and mortality were monitored daily. The animals were weighed on days 0,15 and 30 to measure weight gain. On day 15, doses were adjusted for the average body weight of the animals.

After 28 days, the animals were anesthetized with xylazine $(16 \mathrm{mg} / \mathrm{kg})$ and ketamine $(120 \mathrm{mg} / \mathrm{kg})$, and blood samples were collected from the abdominal aorta for complete blood count and biochemical analysis. Subsequently, the animals were euthanized by anesthetic overdose. The hematological parameters analyzed were the red blood cell count $(\mathrm{RBC})$, hemoglobin $(\mathrm{Hb})$ concentration, hematocrit $(\mathrm{Ht})$, mean corpuscular volume (MCV), mean corpuscular hemoglobin $(\mathrm{MCH})$, mean corpuscular hemoglobin concentration $(\mathrm{MCHC})$, platelets (PIt) and white blood cell count (WBC) using species-specific smart cards for rats in the BC-2800Vet Auto Hematology Analyzer (Mindray ${ }^{\circledR}$, China).

The biochemical parameters alanine aminotransferase (ALT), aminotransferase (AST), urea, serum creatinine, total protein and total bilirubin were determined using Labmax Plenno (Labtest ${ }^{\circledR}$, Minas Gerais, Brazil).

For histopathological analysis, fragments of organs (liver, stomach, lung and kidney) were fixed in 10\% buffered formaldehyde, processed, infiltrated and embedded in paraffin, and $5 \mu \mathrm{m}$ sections were laminated and stained with hematoxylin-eosin for microscopic examination.

\section{Molecular characterization of the anthelmintic resistance of the Haemonchus contortus isolate}

Coprocultures were performed using the method described by Roberts \& O'sullivan (1950) for all animals used in the FECRT. Third-stage larvae (L3) of $H$. contortus were recovered from coprocultures and characterized as resistant to benzimidazoles and levamisole by qPCR. The L3 DNA extraction protocol was performed according to Santos et al. (2014). The extracted DNA was resuspended in $50 \mu \mathrm{L}$ of TE buffer, quantified by spectrophotometry, analyzed by agarose gel electrophoresis to determine its integrity and stored at $-20^{\circ} \mathrm{C}$ until use.

\section{Real-time PCR for resistance to benzimidazoles}

Real-time PCR assays (qPCR), using primers previously described by Santos et al. (2014), were performed in triplicate. Each reaction consisted of a total volume of $25 \mu \mathrm{L}$, containing $12.5 \mu \mathrm{L} 2 \mathrm{X}$ Fast Start Universal SYBR Green Master Mix, $0.3 \mu \mathrm{mol} / \mu \mathrm{L}$ of the primers (sense and antisense) and $25 \mathrm{ng}$ of the pooled DNA sample. Reactions were performed with a Mastercycler ep Realplex (Eppendorf ${ }^{\circledR}$, Hamburg, Germany) and consisted of initial incubation at $95^{\circ} \mathrm{C}$ for 10 min, followed by 35 two-step cycles for SNPs F200Y and F167Y and 34 two-step cycles for SNP E198A: denaturation at $95^{\circ} \mathrm{C}$ for $15 \mathrm{~s}$ and annealing and extension at $58^{\circ} \mathrm{C}$ for $30 \mathrm{~s}$. The qPCR products were differentiated from primer dimers by melting curve analysis. The negative control was performed without sample DNA.

\section{Real-time PCR for resistance to levamisole}

Real-time PCR assays using primers previously described by Santos et al. (2019) were performed in triplicate. Reactions were performed containing $12.5 \mu \mathrm{L}$ SYBR Green (Roche, West Sussex, UK), $0.3 \mathrm{pmol} / \mu \mathrm{L}$ of each primer (Table 1), $50 \mathrm{ng}$ DNA and water for a total 
volume of $25 \mu \mathrm{L}$. Water was used as a negative control instead of DNA. The amplification conditions for both alleles were $95^{\circ} \mathrm{C}$ for $10 \mathrm{~min}$ and 35 cycles of $95^{\circ} \mathrm{C}$ for $15 \mathrm{~s}$ and $56^{\circ} \mathrm{C}$ for $30 \mathrm{~s}$. The melting curve analysis was performed to detect primer dimers.

Table 1. Kinetics of release of nanoencapsulated carvacryl acetate at acidic pH (3) and basic pH (8).

\begin{tabular}{cccccccc}
\hline \multirow{2}{*}{ pH } & \multicolumn{7}{c}{ Correlation coefficient $\left.\mathbf{( R}_{\mathbf{2}}\right)$} \\
\cline { 2 - 8 } & $\begin{array}{c}\text { Zero } \\
\text { order }\end{array}$ & $\begin{array}{c}\text { First } \\
\text { order }\end{array}$ & $\begin{array}{c}\text { Hixson- } \\
\text { Crowell }\end{array}$ & Higuchi & $\begin{array}{c}\text { Korsmeyer } \\
\text { Peppas }\end{array}$ & $\boldsymbol{k}$ & $\boldsymbol{n}$ \\
\hline $\mathrm{pH} \mathrm{3}$ & 0.801 & 0.950 & 0.915 & 0.648 & 0.612 & 0.045 & 0.41 \\
\hline $\mathrm{pH} \mathrm{8}$ & 0.851 & 0.748 & 0.784 & 0.926 & 0.909 & 0.127 & 0.55 \\
\hline
\end{tabular}

\section{Fecal Egg Count Reduction Test (FECRT)}

We used forty sheep of both sexes ranging from 6 to 18 months of mixed breed, weighing an average of $30 \mathrm{~kg}$ and kept in semi-extensive management, fed on native pastures in a semiarid region of northeastern Brazil. The selected animals were naturally infected with gastrointestinal nematodes and had over 500 eggs per gram of feces (epg) using the McMaster technique (Ueno \& Gonçalves, 1998).

$A$ value lower than the $L_{50}$ value established in the acute toxicity test was used to ensure that the CVA (Andre et al., 2016) and nCVA would not cause any toxic effects on sheep. Sheep were divided into 4 groups $(n=10)$ according to epg and randomly assigned to the following treatments: G1: $250 \mathrm{mg} / \mathrm{kg}$ CVA; G2: nCVA; G3: polymer matrix (negative control) and G4: $2.5 \mathrm{mg} / \mathrm{kg}$ monepantel (Zolvix ${ }^{\circledR}$, Novartis, New Zealand) (positive control). Sheep received a single treatment. Fecal samples from each animal were collected on days 0,8 and 16 posttreatment to determine the epg. Coprocultures were performed using the method described by Roberts \& O'sullivan (1950) and 100 larvae were identified according to Van Wyk \& Mayhew (2013).

\section{Statistical analysis}

Data of hematological and biochemical variables of rats were submitted to ANOVA and means compared by Tukey's test using GraphPad Prism ${ }^{\circledR} 5.0$ software (GraphPad Software Inc., USA). The significance level was $p<0.05$.

The efficacy of FECRT was calculated by the BootStreet program through arithmetic average, using the formula:

FECRT $=100 x\left(1-\frac{\mathbf{T} 2}{\mathbf{T} 1} \times \frac{\mathbf{C} 1}{\mathbf{C} 2}\right)^{\cdot}$

In this formula, the arithmetic FECRT means in controls (C) and treated (T) animals before ( $\mathrm{T} 1$ and $\mathrm{C} 1$ ) and 8 or 16 days after ( $\mathrm{T} 2$ and $\mathrm{C} 2$ ) deworming were compared (Dash et al., 1988; Cabaret, 2014). The epg values were log transformed $(\log 10[x+1])$, submitted to ANOVA and compared using the Tukey's test with GraphPad Prism ${ }^{\circledR} 5.0$ software. The significance level was $p<0.05$. The confidence interval of the percentage of L3 recovered in coprocultures was calculated according to the following formula:

$1.96 \sqrt{\frac{p x q}{n}}$ Where $\mathrm{p}$ is the total percentage of larvae of a nematode genus, $\mathrm{q}$ is the total percentage of the other genera of nematodes and $n$ is the total percentage larvae of nematodes identified. 


\section{Results}

GC-MS analysis identified two compounds corresponding to CVA (99.3\%) and carvacrol (0.7\%) (Supplementary Material Figure S1) (supplementary material). The EE and yield of nCVA were $65 \%$ and $57 \%$, respectively.

The FTIR spectra of CVA, chitosan, gum arabic and nCVA are shown in Figure 1. CVA presented the following bands: $1590 \mathrm{~cm}^{-1}$ (C-H flexion), $1765 \mathrm{~cm}^{-1}$ (acetyl group) and 816 $\mathrm{cm}^{-1}$ (aromatic ring) (Andre et al., 2016). The $1086 \mathrm{~cm}^{-1}$ (C-O-C stretch) and $890 \mathrm{~cm}^{-1}$ (pyranose ring) bands correspond to chitosan (Keawchaoon \& Yoksan, 2011). The gum arabic presented $1420 \mathrm{~cm}^{-1}$ ( $\mathrm{C}=\mathrm{O}$ symmetric stretching) and $1366 \mathrm{~cm}^{-1}(-\mathrm{OH}$ bending) bands, indicating the presence of glucuronic acid (Daoub et al., 2018). The spectra of nCVA presented a $1418 \mathrm{~cm}^{-1}$ ( $\mathrm{C}=\mathrm{O}$ symmetric stretching) band, indicating the presence of glucuronic acid in the gum arabic; $1092 \mathrm{~cm}^{-1}$ (C-O-C stretch) and $894 \mathrm{~cm}^{-1}$ (pyranose ring) bands were present in chitosan (Keawchaoon \& Yoksan, 2011). CVA was not detected, possibly due to overlap with other bands of the biopolymer matrix.

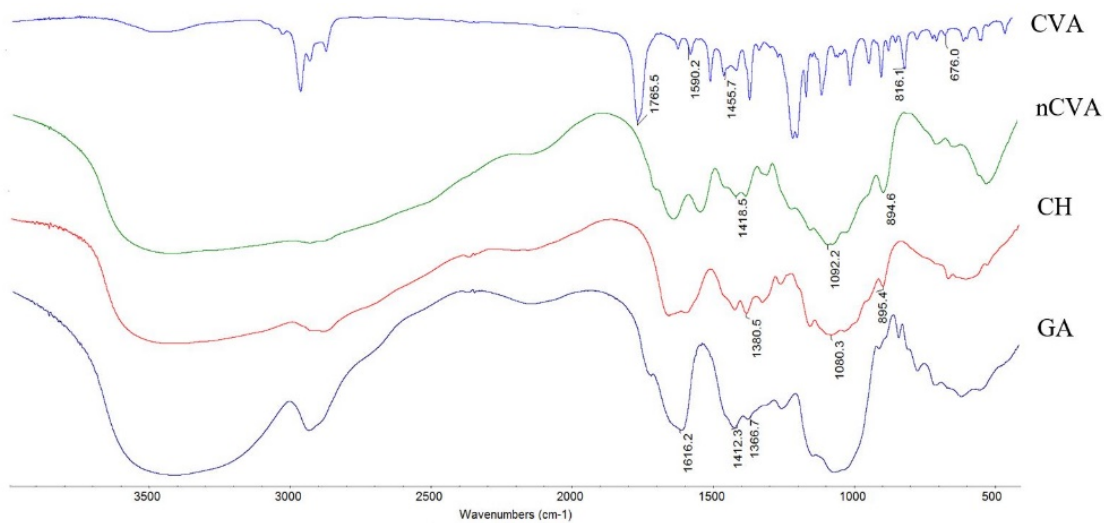

Figure 1. FTIR spectra of carvacryl acetate (CVA), nanoencapsulated carvacryl acetate (nCVA), chitosan $(\mathrm{CH})$ and gum arabic (GA).

Scanning electron microscopy demonstrated that the nCVA nanoparticles had a spherical morphology and agglomeration of the nanoparticles was observed due to the centrifugation process performed prior to lyophilization (Figure 2). The average size of the nanoparticles was $810.6 \pm 286.7 \mathrm{~nm}$ and unimodal distribution (Figure 3). The nanoparticles showed a decrease in the zeta potential with increasing pH. At pH 3.2, the zeta potential was $+18.3 \mathrm{mV}$, and the point of zero charge was situated at approximately pH 5.1 (Figure 4). 


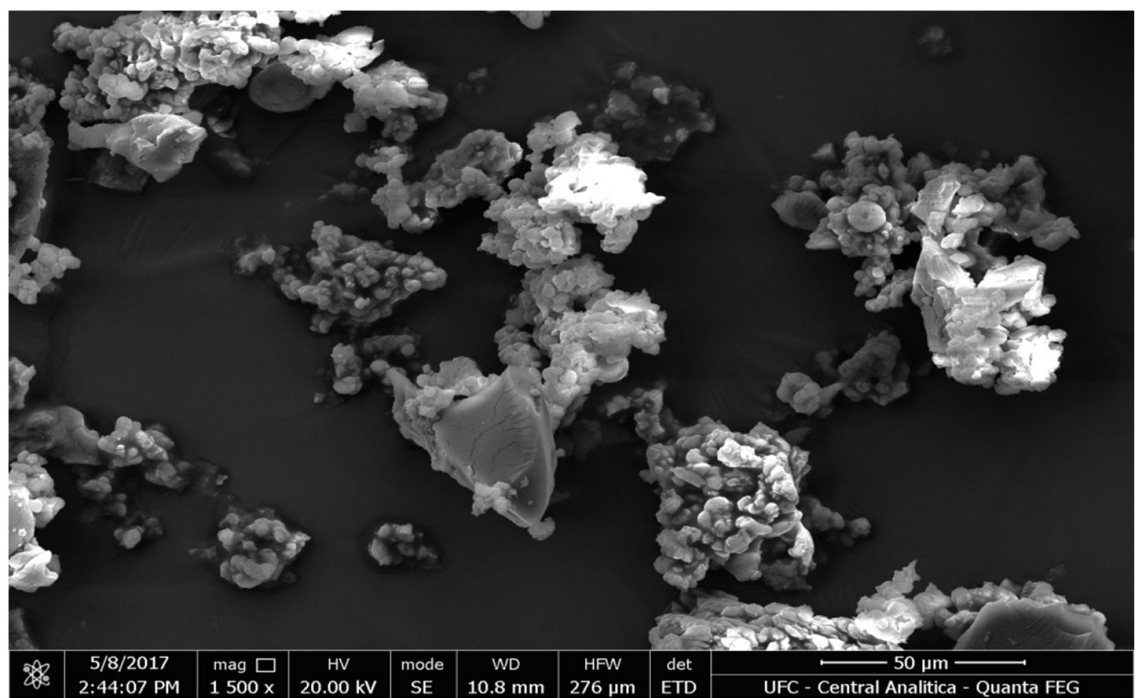

Figure 2. Scanning electron microscopy (SEM) analysis of nanoparticles of carvacryl acetate.

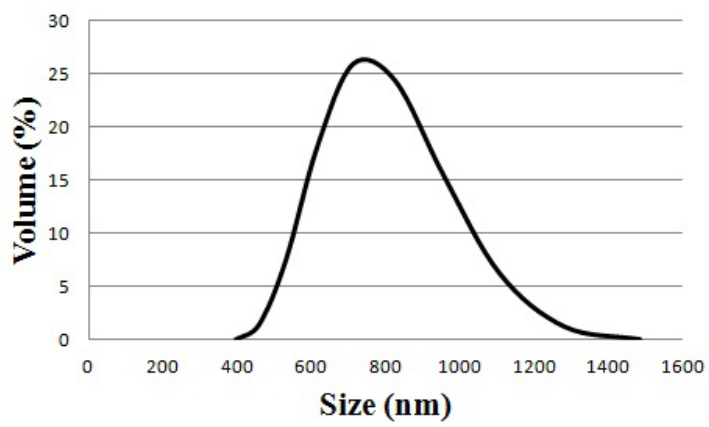

Figure 3. Particle size distribution of the nanoparticles of carvacryl acetate.

Isoelectric Titration Graph

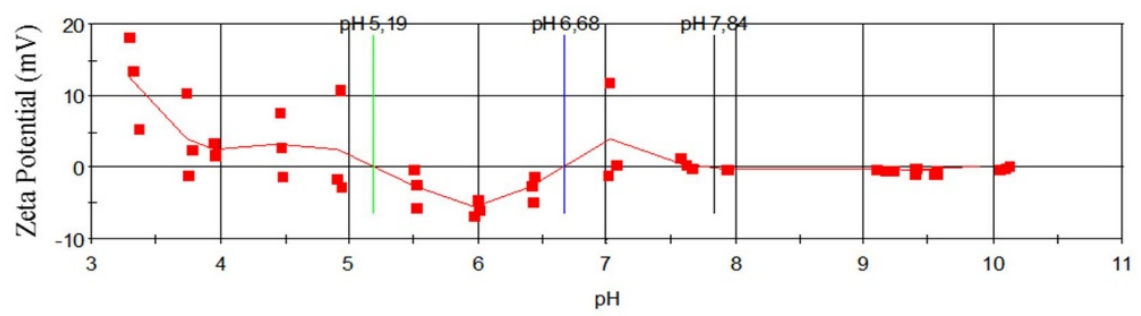

Figure 4. Zeta potential variation with $\mathrm{pH}$ for nanoencapsulated carvacryl acetate. Zeta potential (- ), weighted mean zeta potential (-), $\mathrm{pH} 5.1(-), \mathrm{pH} 6.6(-)$ and $\mathrm{pH} 7.8(-)$.

The kinetics of nCVA release at $\mathrm{pH} 3$ and $\mathrm{pH} 8$ are shown in Figure 5. At pH 3, there was a release of approximately 50\% of CVA after $200 \mathrm{~h}$. The equilibrium was achieved after $240 \mathrm{~h}$, with approximately $93 \%$ of the CVA released into the medium. However, at pH 8 , the release was faster, and approximately $50 \%$ of CVA was released after $10 \mathrm{~h}$. Equilibrium was achieved after $48 \mathrm{~h}$, with approximately $97 \%$ of the CVA released. 

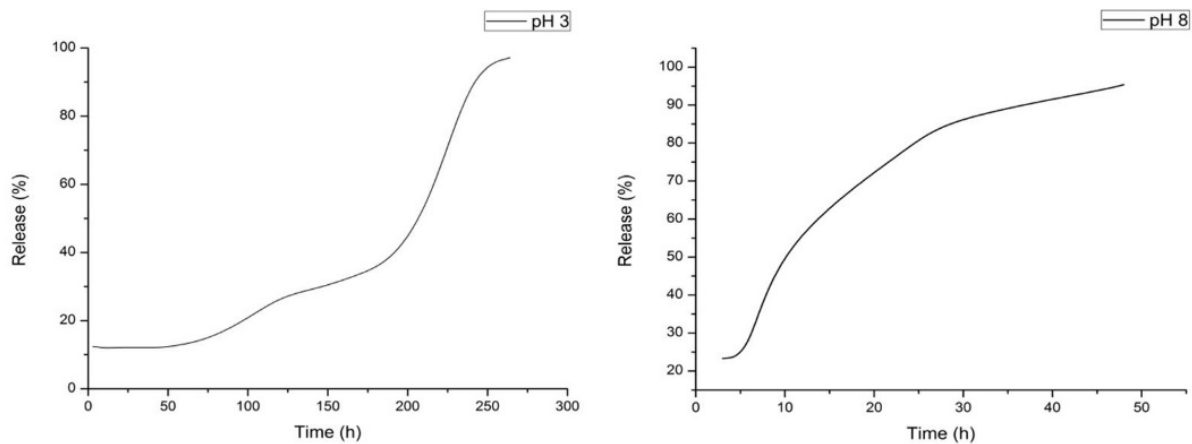

Figure 5. Kinetics of in vitro release of nanoencapsulated carvacryl acetate at acidic pH (3) and basic pH (8).

The best correlation coefficient of nCVA released at $\mathrm{pH} 3$ was first-order model. Higuchi and Korsmeyer-Peppas are the models that represent the release of nCVA in pH 8. The Korsmeyer-Peppas kinetic parameters were calculated and coefficient $\mathrm{n}$ was 0.55 (Table 1).

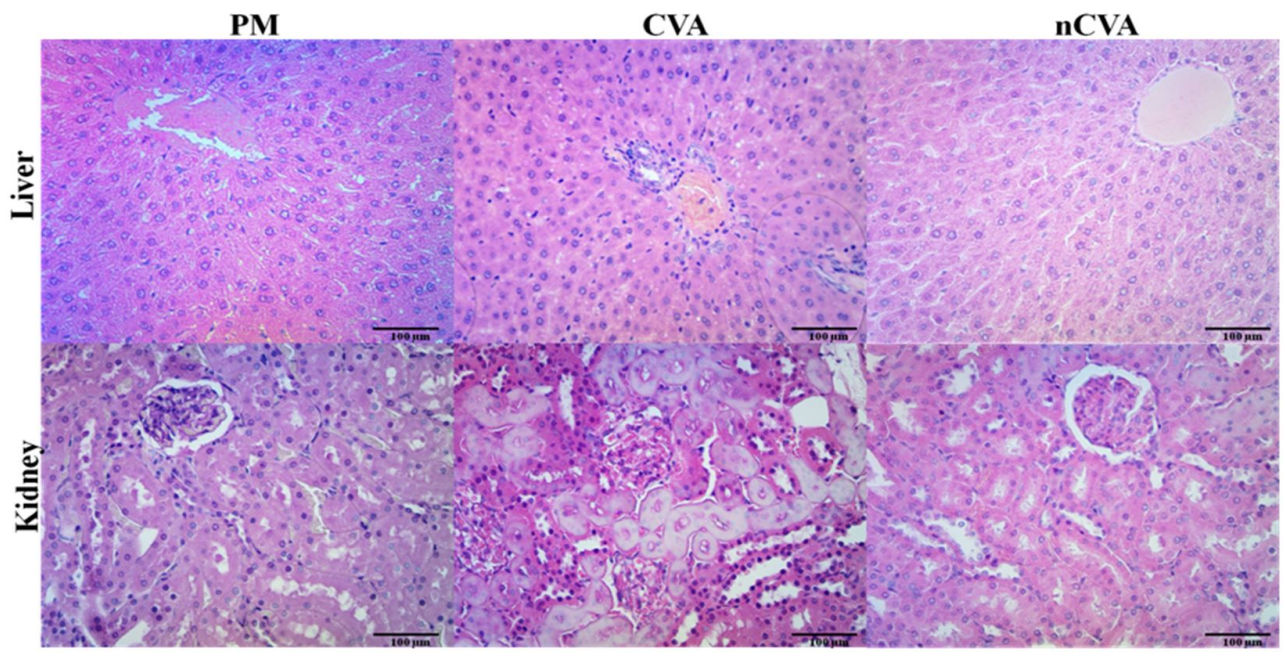

Figure 6. Histological analysis of Rattus novergicus kidney and liver treated for 28 days with $250 \mathrm{mg} / \mathrm{kg}$ polymer matrix (chitosan/gum arabic) (PM), carvacryl acetate (CVA), nanoencapsulated carvacryl acetate (nCVA).

In the acute toxicity test, nCVA presented an $L_{50}$ value of $2,609 \mathrm{mg} / \mathrm{kg}$. The encapsulating matrix showed no toxicity. In the subchronic toxicity test, the results of the biochemical and hematological parameters of rats treated with CVA, nCVA and the polymer matrix showed that the parameters did not differ significantly among the studied groups (Table 2). Hepatic changes were observed (hepatocyte cell swelling, Kupffer cell hyperplasia, portal and centrilobular vein congestion, and the presence of inflammatory cells) in animals treated with CVA and nCVA. In the kidneys of all treated animals, moderate swelling of the tubular epithelium, sections with isomeric vacuolization of tubular epithelium and hyaline cylinders were observed. In the spleen, ectasia was observed with inflammatory cell visualization inside the vessels, in addition to brownish and/or blackish pigments suggestive of lipofuscin and hemosiderin, respectively. Lung, stomach and intestine samples did not present morphological alterations (Figure 6). 
Table 2. Hematological and biochemical parameters ( \pm standard deviation) of Albino Wistar rats treated with carvacryl acetate $(250 \mathrm{mg} / \mathrm{kg})$, nanoencapsulated carvacryl acetate $(250 \mathrm{mg} / \mathrm{kg})$ and polymer matrix (negative control).

\begin{tabular}{ccccc}
\hline Parameters & $\begin{array}{c}\text { Carvacryl } \\
\text { acetate }\end{array}$ & $\begin{array}{c}\text { Nanoencapsulated } \\
\text { carvacryl acetate }\end{array}$ & $\begin{array}{c}\text { Polymer matrix } \\
\text { (negative control }\end{array}$ & Reference $^{\text {a }}$ \\
\hline $\mathrm{WCB}\left(10^{3} / \mu \mathrm{L}\right)$ & $4 \pm 0.9^{\mathrm{A}}$ & $5.1 \pm 1.5^{\mathrm{A}}$ & $4.6 \pm 0.6^{\mathrm{A}}$ & $4.7-12.9$ \\
\hline $\mathrm{RBC}\left(10^{6} / \mu \mathrm{L}\right)$ & $8 \pm 0.4^{\mathrm{A}}$ & $7.5 \pm 0.3^{\mathrm{A}}$ & $7.3 \pm 0.6^{\mathrm{A}}$ & $7.3-8.6$ \\
\hline $\mathrm{Hb}(\mathrm{g} / \mathrm{dL})$ & $15.4 \pm 1.0^{\mathrm{A}}$ & $14.7 \pm 0.9^{\mathrm{A}}$ & $14.1 \pm 0.8^{\mathrm{A}}$ & $13.2-15.1$ \\
\hline $\mathrm{Ht}(\%)$ & $48.7 \pm 3.2^{\mathrm{A}}$ & $46.6 \pm 2.9^{\mathrm{A}}$ & $44.7 \pm 2.3^{\mathrm{A}}$ & $39.1-48.5$ \\
\hline $\mathrm{PIt}\left(10^{3} / \mu \mathrm{l}\right)$ & $830.1 \pm 123.9^{\mathrm{A}}$ & $939 \pm 128.5^{\mathrm{A}}$ & $1,128 \pm 118.7^{\mathrm{B}}$ & $757-1476$ \\
\hline $\mathrm{MCV}\left(\mu \mathrm{m}^{3}\right)$ & $60.8 \pm 0.8^{\mathrm{A}}$ & $61.4 \pm 2.0^{\mathrm{A}}$ & $60.3 \pm 1.2^{\mathrm{A}}$ & $49.1-62.5$ \\
\hline $\mathrm{MCHC}(\%)$ & $31.7 \pm 0.4^{\mathrm{A}}$ & $31.5 \pm 0.3^{\mathrm{A}}$ & $31.5 \pm 0.5^{\mathrm{A}}$ & $29.9-34.9$ \\
\hline $\mathrm{ALT}(\mathrm{UI} / \mathrm{L})$ & $44.2 \pm 9.6^{\mathrm{A}}$ & $58.7 \pm 31.4^{\mathrm{A}}$ & $54 \pm 17.8^{\mathrm{A}}$ & $26-60$ \\
\hline $\mathrm{AST}(\mathrm{UI} / \mathrm{L})$ & $72.8 \pm 15^{\mathrm{A}}$ & $126.5 \pm 24.6^{\mathrm{B}}$ & $87.1 \pm 29.8^{\mathrm{B}}$ & $83-184$ \\
\hline $\mathrm{CR}(\mathrm{mg} / \mathrm{dL})$ & $0.7 \pm 21.5^{\mathrm{A}}$ & $0.96 \pm 0.48^{\mathrm{A}}$ & $0.71 \pm 0.3^{\mathrm{A}}$ & $0.4-0.7$ \\
\hline $\mathrm{UR}(\mathrm{mg} / \mathrm{dL})$ & $56 \pm 6.32^{\mathrm{A}}$ & $69.3 \pm 34.9^{\mathrm{A}}$ & $56.5 \pm 4.5^{\mathrm{A}}$ & $30-57$ \\
\hline $\mathrm{ALB}(\mathrm{g} / \mathrm{dL})$ & $3.41 \pm 0.35^{\mathrm{A}}$ & $3.95 \pm 1.2^{\mathrm{A}}$ & $3.3 \pm 0.4^{\mathrm{A}}$ & $2.6-3.4$ \\
\hline
\end{tabular}

Different letters indicate significantly different averages in the rows $(\mathrm{P}<0.05)$. The polymer matrix (chitosan/arabic gum) was a negative control. The animals were randomly divided into 3 groups $(n=8)$. The hematological parameters analyzed were the white blood cell count (WBC), red blood cell count (RBC), hemoglobin $(\mathrm{Hb})$, hematocrit $(\mathrm{Ht})$, mean corpuscular volume $(\mathrm{MCV})$, mean corpuscular hemoglobin $(\mathrm{MCHC})$, mean corpuscular hemoglobin concentration (MCHC), and platelets (PIt) and biochemical parameters were alanine aminotransferase (ALT), aminotransferase (AST), creatinine (CR), UR (urea) and albumin (ALB). ${ }^{\text {a }}$ The reference values established by Melo et al. (2012).

The molecular characterization of $\mathrm{H}$. contortus demonstrated that the isolate has a higher frequency of SNP F167Y resistant alleles. For levamisole, frequencies of 64\% resistant alleles of the $63 \mathrm{bp}$ indel of exon 3 of the Hco-acr-8 gene were identified (Table 3).

Table 3. Sensitive and resistant allele frequencies for SNPs 200Y, 167Y, 198A and Hco-acr-8 gene em Haemonchus contortus isolate from farm.

\begin{tabular}{cccc}
\hline Anthelmintics & SNPs & Allele & $\begin{array}{c}\text { Frequency of each } \\
\text { allele (\%) }\end{array}$ \\
\hline Benzimidazoles & F200Y & Sensitive & $33.3 \%$ \\
\hline & & Resistant & $66.7 \%$ \\
\hline & F167Y & Sensitive & $28 \%$ \\
\hline \multirow{2}{*}{ Levamisole } & & Resistant & $72 \%$ \\
\hline \multirow{2}{*}{ Hco-acr-8 gene } & Sensitive & $100 \%$ \\
\cline { 2 - 4 } & & Resistant & - \\
\hline
\end{tabular}

The FECRT results of CVA, nCVA and monepantel are expressed as the mean epg on days 0,8 and 16 posttreatment (Table 4). CVA, nCVA and monepantel reduced the epg by $57.7 \%, 51.1 \%$ and $97.7 \%$, respectively, by 16 days posttreatment. The results of CVA and nCVA were not significantly different from the negative control $(p>0.05)$. The prevalence of nematode genera in FECRT is presented in Table 5. After treatment, the frequency of Trichostrongylus spp. increased in relation to Haemonchus spp. in the groups treated with CVA and nCVA, indicating that this biocomposite is effective against Haemonchus spp. 
Table 4. Mean efficacy and egg counts per gram of faeces (epg \pm standard deviation) of sheep treated with of carvacryl acetate (CVA), nanoencapsulated carvacryl acetate (nCVA) or monepantel.

\begin{tabular}{|c|c|c|c|}
\hline Treatments & Day 0 & Day 8 & Day 16 \\
\hline \multicolumn{4}{|l|}{ CVA } \\
\hline Mean epg & $1915 \pm 1131^{\mathrm{Aa}}$ & $1140 \pm 1074^{\mathrm{Aa}}$ & $585 \pm 788.9^{\mathrm{Aa}}$ \\
\hline Efficacy (\%) & - & 9.6 & 57.7 \\
\hline \multicolumn{4}{|l|}{ nCVA } \\
\hline Mean epg & $1885 \pm 1039 \mathrm{Aa}$ & $695 \pm 185^{\mathrm{Ba}}$ & $665 \pm 261^{\mathrm{Ca}}$ \\
\hline Efficacy (\%) & - & 44 & 51.1 \\
\hline \multicolumn{4}{|l|}{ Monepantel } \\
\hline Mean epg & $1865 \pm 748.1^{\mathrm{Aa}}$ & $125 \pm 182.7^{\mathrm{Bb}}$ & $30 \pm 44.4^{\mathrm{cb}}$ \\
\hline Efficacy (\%) & & 89.7 & 97.7 \\
\hline \multicolumn{4}{|l|}{$\begin{array}{l}\text { Polymer matrix } \\
\text { (negative control) }\end{array}$} \\
\hline Mean epg & $1875 \pm 1175^{\mathrm{Aa}}$ & $1235 \pm 562^{\mathrm{Aa}}$ & $1355 \pm 455^{\text {Aa }}$ \\
\hline \multicolumn{4}{|c|}{$\begin{array}{l}\text { Different capital letters in the rows and small letters in the columns indicate significantly different means }(\mathrm{P}<0.05) \text {. The } \\
\text { animals were randomly divided into } 4 \text { groups }(\mathrm{n}=10) \text {. The efficacy was calculated using the formula } 100 \times(1-[T 2 / \mathrm{T} 1] \\
\text { [C1/C2]), in which the arithmetic fecal egg count means in controls }(\mathrm{C}) \text { and treated }(\mathrm{T}) \text { animals before }(\mathrm{T} 1 \text { and } \mathrm{C} 1) \text { and } 8 \text { or } \\
16 \text { days after ( }(\mathrm{T} 2 \text { and } \mathrm{C} 2 \text { ) deworming were compared (Dash et al., 1988). }\end{array}$} \\
\hline
\end{tabular}

Table 5. Frequency (\%) and 95\% confidence interval of third stage larvae identified in coprocultures on days 0,8 and 16 posttreatment.

\begin{tabular}{|c|c|c|c|}
\hline Groups & Day 0 & Day 8 & Day 16 \\
\hline \multicolumn{4}{|l|}{ CVA } \\
\hline Haemonchus spp. & $65(55.4-74.5)$ & $23(14.5-31.4)$ & $27(18.1-35.8)$ \\
\hline Trichostrongylus spp. & $32(22.6-41.3)$ & $73(63.8-81.8)$ & $70(60.8-79.1)$ \\
\hline Oesophagostomum spp. & $3(-0.4-6.4)$ & $4(0.5-7.9)$ & $3(-0.4-6.4)$ \\
\hline \multicolumn{4}{|l|}{ nCVA } \\
\hline Haemonchus spp. & $60(50.2-69.7)$ & $27(18.1-35.8)$ & $31(21.7-40.2)$ \\
\hline Trichostrongylus spp. & $38(28.2-47.7)$ & $70(60.8-79.1)$ & $65(55.4-74.5)$ \\
\hline Oesophagostomum spp. & $2(-0.2-4.2)$ & $3(1.1-4.8)$ & $4(1.6-6.3)$ \\
\hline \multicolumn{4}{|l|}{ Negative control } \\
\hline Haemonchus spp. & $65(55.4-74.5)$ & $58(43-67.8)$ & $53(43-62.9)$ \\
\hline Trichostrongylus spp. & $35(28-42)$ & $38(30-45.9)$ & $44(34.9-53)$ \\
\hline Oesophagostomum spp. & 0 & $4(1.4-6.5)$ & $3(0.6-5.3)$ \\
\hline \multicolumn{4}{|l|}{ Positive control } \\
\hline Haemonchus spp. & $70(60.8-79.1)$ & $47(37-56.9)$ & $50(40-60)$ \\
\hline Trichostrongylus spp. & $26(20.4-31.5)$ & $44(34.3-53.6)$ & $38(29.2-46.6)$ \\
\hline Oesophagostomum spp. & $4(1.8-6.1)$ & $9(4.6-13.3)$ & $12(7.1-16.9)$ \\
\hline
\end{tabular}

Groups were treated with $250 \mathrm{mg} / \mathrm{kg}$ CVA (carvacryl acetate) or nCVA (nanoencapsulated carvacryl acetate). The positive control group was treated with $2.5 \mathrm{mg} / \mathrm{kg}$ monepantel (Zolvix ${ }^{\circledR}$ ), and the negative control group received polymer matrix.

\section{Discussion}

The control of gastrointestinal nematodes that are resistant and/or multiresistant to synthetic anthelmintics is one of the great challenges of sheep and goat breeding worldwide. The use of nanostructured bioactive compounds has been highlighted as a promising alternative to be used in the integrated management of these nematodes (Mesquita et al., 2013; Ribeiro et al., 2013, 2015, 2017). 
In the evaluation of the zeta potential of nCVA at different $\mathrm{pH}$ values ( 3 and 8 ), the nanoparticles were more stable at $\mathrm{pH} 3.2$, where they had a zeta potential of $+18.3 \mathrm{mV}$. The positive zeta potential of nCVA at acidic $\mathrm{pH}$ occurred due to the protonation of the amine groups of chitosan, increasing the positive charges on the surface of the nanoparticles. These positively charged nanoparticles can interact electrostatically with the negative charges of components present in the mucus that protect the mucosa of the stomach of monogastric animals, resulting in the mucoadhesion of nanoparticles (Ways et al., 2018). The acidic pH of ovine abomasum may promote the deprotonation of chitosan, adhesion of nanoparticles to the abomasal mucosa and prolonged release of CVA. However, for nanoparticles that do not adhere to the abomasal mucosa and reach the small intestine where the $\mathrm{pH}$ is basic, deprotonation of the amine groups of chitosan occurs and the carboxyl groups of gum arabic are ionized, which reduces the zeta potential of the nanoparticles and approaches the isoelectric point, where charge neutralization occurs (Abreu et al., 2008), and consequently, the nanoencapsulated biocomposite is rapidly released.

The in vitro profile of the sustained release of nCVA was evaluated at $\mathrm{pH} 3$ and 8 to simulate the release of this biocomposite in the gastrointestinal tract of the small ruminants. In the present study, at $\mathrm{pH} 3$, the system followed first-order kinetics, where the CVA was released in a constant proportion per unit time and the rate of elimination was proportional to the amount of CVA within the particle. In this sense, the total amount of drug released decreased with time (Costa, 2002). However, at pH 8, nanoparticles followed the Higuchi and Korsmeyer-Peppas model. The Higuchi model states that the system follows the diffusional behavior; Korsmeyer-Peppas aims to identify the type of diffusion through coefficient $\mathrm{n}$. The coefficient $\mathrm{n}$ was 0.55 , presenting a release with non-Fickian behavior (anomalous transport), where the release occurs by mechanisms of diffusion and relaxation of the polymer chain (Costa, 2002). The release of nCVA in the in vitro tests at abomasal and small intestine $\mathrm{pH}$ values allowed us to verify that the nanoparticles at acidic $\mathrm{pH}$ slowly released CVA, which is related to the protonation of chitosan amino groups. In the basic $\mathrm{pH}$ of the intestine, the amine groups of chitosan were deprotonated, leading to a faster release.

The $L_{50}$ of nCVA was $2,609 \mathrm{mg} / \mathrm{kg}$, while the $L_{50}$ of CVA was $1,544.5 \mathrm{mg} / \mathrm{kg}$ obtained from the acute toxicity test in mice (Andre et al., 2016). The nanoencapsulation of CVA reduced toxicity and increased the toxicology safety of this biocomposite. The reduction in toxicity of a nanoencapsulated essential oil was also verified when evaluating the acute toxicity of Eucalyptus stageriana essential oil $\left(\mathrm{LD}_{50}=1,603.9 \mathrm{mg} / \mathrm{kg}\right)$ and its nanoemulsion $\left(\mathrm{LD}_{50}=3,495.9 \mathrm{mg} / \mathrm{kg}\right.$ ) (Ribeiro et al., 2015). The reduction in toxicity may be associated with the sustained release of these biocomposites, maintaining their therapeutic effect and reducing the occurrence of plasma peaks that may trigger toxic effects on animal cells. However, in the subchronic toxicity analysis, CVA and nCVA did not cause changes in hepatic and renal biochemical parameters. However, histopathological alterations were observed in these organs. Hepatic and renal cell hyperplasia was the mechanism of adaptation of these organs to the stress of metabolizing and excreting CVA daily for 28 days. However, these changes were reversible (Vasconcelos et al., 2007).

The anthelmintics most frequently used in the control of gastrointestinal nematodes in the Brazilian Northeast are benzimidazol, ivermectin and levamisole. The use of these drugs has promoted the selection of multiresistant nematode populations (Silva et al., 2018). The molecular characterization of $H$. contortus anthelmintic resistance isolated from experimental animals demonstrated that the population was resistant to benzimidazol and levamisole. A study carried out in Ceará state, Northeast Brazil found that the anthelmintic used by $89 \%$ of the farms was LEV (Santos et al. 2017).

Thus, the control of these populations of multiresistant nematodes is one of the obstacles to maintaining animal health, and the use of nanostructured bioactive compounds may be an alternative control. The efficacy of $250 \mathrm{mg} / \mathrm{kg}$ CVA on ovine gastrointestinal nematodes was $65.9 \% 16$ days posttreatment (Andre et al., 2016). In the 
present study, there was a reduction in the efficacy of CVA and there was no statistical difference $(p>0.05)$ between the value of epg in the treated and the control groups. Similar results were verified when evaluating the efficacy of the essential oil of free Eucalyptus citriodora and its nanoemulsion in that same period (Ribeiro et al., 2014). The efficacy of nCVA was similar to that of CVA, and there was a reduction in Haemonchus spp. L3 percentage and a resulting increase in Trichostrongylus spp. L3 in posttreatment coprocultures. The activity of CVA against Haemonchus spp. was likely improved by the encapsulation process with chitosan, which is a bioadhesive polymer that is used in drug delivery systems, by promoting a sustained release in acidic $\mathrm{pH}$, increasing the bioavailability of CVA and hence potentiating anthelmintic efficacy. Similar results were found when evaluating the anthelmintic activity of chitosan-nanoencapsulated E. staigeriana essential oil on the parasite load of sheep infected with Haemonchus spp., Trichostrongylus spp. and Oesophagostomum spp., where only the parasite load of Haemonchus spp. was reduced (Mesquita et al., 2013). In addition, efficacy has been shown to vary according to nematode species, particularly when they inhabit separate digestive organs (Hoste et al., 2008).

The nanoencapsulation system was effective, presenting a nanometric size, zeta potential and sustained release in acidic $\mathrm{pH}$, besides to reducing the toxicity of the biocomposite. Thus, studies evaluating the anthelmintic action of CVA in experimentally infected animals with gastrointestinal nematodes should be performed. In addition, the bioavailability assessment should be evaluated to analyze the sustained release of CVA.

\section{Acknowledgements}

Coordenação de Aperfeiçoamento de Pessoal de Nível Superior (CAPES) and Conselho Nacional de Desenvolvimento Científico e Tecnológico (CNPq) provided financial support. Dr. Bevilaqua has a researcher fellowship from CNPq (303018/2013-5).

\section{References}

Abreu FOMS, Bianchini C, Forte MMC, Kist TBL. Influence of the composition and preparation method on the morphology and swelling behavior of alginate-chitosan hydrogels. Carbohydr Polym 2008; 74(2): 283-289. http://dx.doi.org/10.1016/j.carbpol.2008.02.017.

Abreu FOMS, Castro AM, Silva PV, Cavalcante LG, Nascimento AP, Matos JEX. Propriedades e características de Quitosana obtida a partir do exoesqueleto de Caranguejo-Uçá utilizando radiação de microondas. Polímeros 2013; 23(5): 630-635. http://dx.doi.org/10.4322/polimeros.2013.042.

Adams RP. Identification of Essential oil Components by Gas Chromatography/Mass Spectrometry. 4th ed. Carol Stream: Allured Publishing Corporation; 2007.

Andre WPP, Ribeiro WLC, Cavalcante GS, Santos JML, Macedo ITF, Paula HCB, et al. Comparative efficacy and toxic effects of carvacryl acetate and carvacrol on sheep gastrointestinal nematodes and mice. Vet Parasitol 2016; 218: 52-58. http://dx.doi.org/10.1016/j.vetpar.2016.01.001. PMid:26872928.

Araújo-Filho JV, Ribeiro WLC, André WPP, Cavalcante GS, Guerra MCM, Muniz CR, et al. Effects of Eucalyptus citriodora essential oil and its major component, citronellal, on Haemonchus contortus isolates susceptible and resistant to synthetic anthelmintics. Ind Crops Prod 2018; 124: 294-299. http://dx.doi.org/10.1016/j.indcrop.2018.07.059.

Besier RB, Kahn LP, Sargison ND, Van Wyk JA. The pathophysiology, ecology and epidemiology of Haemonchus contortus infection in small ruminants. Adv Parasitol 2016; 93: 95-143. http://dx.doi.org/10.1016/bs.apar.2016.02.022. PMid:27238004.

Cabaret J. Reliable phenotypic evaluations of anthelmintic resistance in herbivores: how and when should. They be done? In: Quick W. (Ed.). Anthelmintics - Clinical pharmacology, uses in veterinary medicine and efficacy. Nova Science Publisher, New York; 2014. p. 1-26 
Costa PJC. Avaliação in vitro da lioequivalência de formulações farmacêuticas. Rev Bras Cienc Farm 2002; 38(2): 141-153. http://dx.doi.org/10.1590/S1516-93322002000200003.

Daoub RMA, Elmubarak AH, Misran M, Hassan EA, Osman ME. Characterization and functional properties of some natural Acacia gums. J Saudi Soc Agric Sci 2018; 17(3): 241-249. http://dx.doi.org/10.1016/j.jssas.2016.05.002.

Dash KM, Hall K, Barger IA. The role of arithmetic and geometric mean worm egg counts in faecal egg count reduction tests and in monitoring strategic drenching programs in sheep. Aust Vet J 1988; 65(2): 66-68. http://dx.doi.org/10.1111/j.1751-0813.1988.tb07359.x. PMid:3355458.

Elmahalawy ST, Halvarsson P, Skarin M, Höglund J. Droplet digital polymerase chain reaction (ddPCR) as a novel method for absolute quantification of major gastrointestinal nematodes in sheep. Vet Parasito/ 2018; 261: 1-8. http://dx.doi.org/10.1016/j.vetpar.2018.07.008. PMid:30253846.

Fabbri J, Maggiore MA, Pensel PE, Denegri GM, Gende LB, Elissondo MC. In vitro and in vivo efficacy of carvacrol against Echinococcus granulosus. Acta Trop 2016; 164: 272-279. http://dx.doi.org/10.1016/j.actatropica.2016.09.001. PMid:27650960.

Guan Y, Zhong Q. The improved thermal stability of anthocyanins at $\mathrm{pH}$ 5.0. by gum Arabic. Lebensm Wiss Technol 2015; 64(2): 706-712. http://dx.doi.org/10.1016/j.Iwt.2015.06.018.

Hoste H, Torres-Acosta JF, Alonso-Diaz MÁ, Brunet S, Sandoval Castro C, Adote SH. Identification and validation of bioactive plants for the control of gastrointestinal nematodes in small ruminants. Trop Biomed 2008;25(1 Suppl): 56-72. PMid:18414378.

Kearney PE, Murray PJ, Hoy JM, Hohenhaus M, Kotze A. The 'Toolbox' of strategies for managing Haemonchus contortus in goats: what's in and what's out. Vet Parasito/ 2016; 220: 93-107. http://dx.doi.org/10.1016/j.vetpar.2016.02.028. PMid:26995728.

Keawchaoon L, Yoksan R. Preparation, characterization and in vitro release study of carvacrol-loaded chitosan nanoparticles. Colloids Surf B Biointerfaces 2011; 84(1): 163-171. http://dx.doi.org/10.1016/j.colsurfb.2010.12.031. PMid:21296562.

Kotze AC, Prichard RK. Anthelmintic resistance in Haemonchus contortus: History, Mechanisms and Diagnosis. Adv Parasito/ 2016; 93: 397-428. http://dx.doi.org/10.1016/bs.apar.2016.02.012. PMid:27238009.

Macedo IT, Bevilaqua CM, Oliveira LM, Camurça-Vasconcelos AL, Vieira LS, Oliveira FR, et al. Anthelmintic effect of Eucalyptus staigeriana essential oil against goat gastrointestinal nematodes. Vet Parasitol 2010; 173(1-2): 93-98. http://dx.doi.org/10.1016/j.vetpar.2010.06.004. PMid:20609526.

Matos FJA. Introdução à fitoquímica experimental. 2. ed. Fortaleza: Edições UFC; 1997.

Melo MGD, Dória GAA, Serafini MR, Araújo AAS. Valores de referência hematológicos e bioquímicos de ratos (Rattus novergicus linhagem Wistar) provenientes do biotério central da Universidade Federal de Sergipe. Scientia Plena 2012; 8(9): 375-399.

Mesquita MA, Silva Júnior JB, Panassol AM, Oliveira EF, Camurça-Vasconcelos ALF, Paula HCB, et al. Anthelmintic activity of Eucalyptus staigeriana encapsulated oil on sheep gastrointestinal nematodes. Parasitol Res 2013; 112(9): 3161-3165. http://dx.doi.org/10.1007/s00436-013-3492-2. PMid:23783400.

Minkal, Ahuja M, Bhatt DC. Polyelectrolyte complex of carboxymethyl gum katira- chitosan: preparation and characterization. Int J Biol Macromol 2018; 106: 1184-1191. http://dx.doi.org/10.1016/j.jjbiomac.2017.08.128. PMid:28851639.

Moraes J, Carvalho AAL, Nakaro E, Almeida AAC, Marques THC, Andrade LN, et al. Anthelmintic activity of carvacryl acetate against Schistosoma mansoni. Parasitol Res 2013; 112(2): 603-610. http://dx.doi.org/10.1007/s00436-012-3172-7. PMid:23086444.

Morais SM, Vila-Nova NS, Bevilaqua CML, Rondon FCM, Lobo CH, Moura AAAN, et al. Thymol and eugenol derivatives as potential antileishmanial agents. Bioorg Med Chem 2014; 22(21): 62506255. http://dx.doi.org/10.1016/j.bmc.2014.08.020. PMid:25281268.

Organization for Economic Cooperation and Development - OECD. Guidelines for the testing of chemicals: acute oral toxicity- upand-down procedure [online]. Paris: OECD; 2008a (Guideline, 425). [cited 2019 Jun 10]. Available from: https://www.oecd-ilibrary.org/environment/test-no-425acute-oral-toxicity-up-and-downprocedure_9789264071049-en. 
Organization for Economic Cooperation and Development - OECD. Guidelines for the testing of chemicals: Repeated Dose 28-Day Oral Toxicity Study in Rodents. Paris: OECD; 2008b (Guideline, 407). [cited 2019 Jun 10]. Available from: https://www.oecd-ilibrary.org/environment/test-no407-repeated-dose-28-day-oral-toxicity-study-in-rodents_9789264070684-en.

Raut JS, Karuppayil SM. A status review on the medicinal properties of essential oils. Ind Crops Prod 2014; 62: 250-264. http://dx.doi.org/10.1016/j.indcrop.2014.05.055.

Ribeiro JC, Ribeiro WLC, Camurça-Vasconcelos ALF, Macedo ITF, Santos JML, Paula HCB, et al. Efficacy of free and nanoencapsulated Eucalyptus citriodora essential oils on sheep gastrointestinal nematodes and toxicity for mice. Vet Parasitol 2014; 204(3-4): 243-248. http://dx.doi.org/10.1016/j.vetpar.2014.05.026. PMid:24929446.

Ribeiro WL, Camurça-Vasconcelos AL, Macedo IT, Santos JM, Araújo-Filho JV, Ribeiro JC, et al. In vitro effects of Eucalyptus staigeriana nanoemulsion on Haemonchus contortus and toxicity in rodents. Vet Parasitol 2015; 212(3-4): 444-447. http://dx.doi.org/10.1016/j.vetpar.2015.07.019. PMid:26233731.

Ribeiro WLC, Camurça-Vasconcelos ALF, Santos JML, Macedo ITF, Ribeiro JC, Oliveira EF, et al. The use of Eucalyptus staigeriana nanoemulsion for control of sheep haemonchosis. Pesq Vet Bras 2017; 37(3): 221-226. http://dx.doi.org/10.1590/s0100-736x2017000300004.

Ribeiro WL, Macedo IT, Santos JM, Oliveira EF, Camurça-Vasconcelos AL, Paula HC, et al. Activity of chitosan-encapsulated Eucalyptus staigeriana essential oil on Haemonchus contortus. Exp Parasitol 2013; 135(1): 24-29. http://dx.doi.org/10.1016/j.exppara.2013.05.014. PMid:23748159.

Roberts FHS, O'Sullivan JP. Methods for egg counts and larval cultures for strongyles infesting the gastrointestinal tract of cattle. Aust J Agric Res 1950; 1(1): 99-102. http://dx.doi.org/10.1071/AR9500099.

Sanchez C, Nigen M, Mejia Tamayo V, Doco T, Williams P, Amine C, et al. Acacia gum: history of the future. Food Hydrocoll 2018; 78: 140-160. http://dx.doi.org/10.1016/j.foodhyd.2017.04.008.

Santos JML, Monteiro JML, Ribeiro WLC, Macedo ITF, Camurça-Vasconcelos ALC, Vieira LS, et al. Identification and quantification of benzimidazole resistance polymorphisms in Haemonchus contortus isolated in Northeastern Brazil. Vet Parasitol 2014; 199(3-4): 160-164. http://dx.doi.org/10.1016/j.vetpar.2013.11.006. PMid:24295955.

Santos JML, Vasconcelos JF, Frota GA, Freitas EP, Teixeira M, Vieira LDS, et al. Quantitative molecular diagnosis of levamisole resistance in populations of Haemonchus contortus. Exp Parasitol 2019; 205: 107734. http://dx.doi.org/10.1016/j.exppara.2019.107734. PMid:31394093.

Santos JML, Vasconcelos JF, Frota GA, Ribeiro WL, André WPP, Vieira LS, et al. Haemonchus contortus $\beta$-tubulin isotype 1 gene F200Y and F167Y SNPs are both selected by ivermectin and oxfendazole treatments with differing impacts on anthelmintic resistance. Vet Parasitol 2017; 248: 90-95. http://dx.doi.org/10.1016/j.vetpar.2017.11.003. PMid:29173548.

Shang X, Wang Y, Zhou X, Guo X, Dong S, Wang D, et al. Acaricidal activity of oregano oil and its major component, carvacrol, thymol and p-cymene against Psoroptes cuniculi in vitro and in vivo. Vet Parasito/ 2016; 226: 93-96. http://dx.doi.org/10.1016/j.vetpar.2016.07.001. PMid:27514892.

Shariatinia Z, Mazloom-Jalali A. Chitosan nanocomposite drug delivery systems designed for the ifosfamide anticancer drug using molecular dynamics simulations. J Mol Liq 2019; 273: 346-367. http://dx.doi.org/10.1016/j.molliq.2018.10.047.

Silva FF, Bezerra HMFF, Feitosa TF, Vilela VLR. Nematode resistance to five anthelmintic classes in naturally infected sheep herds in Northeastern Brazil. Rev Bras Parasito/ Vet 2018; 27(4): 423-429. http://dx.doi.org/10.1590/s1984-296120180071. PMid:30427525.

Tan C, Xie J, Zhang X, Cai J, Xia S. Polysaccharide-based nanoparticles by chitosan and gum Arabic polyelectrolyte complexation as carriers for curcumin. Food Hydrocoll 2016; 57: 236-245. http://dx.doi.org/10.1016/j.foodhyd.2016.01.021.

Ueno H, Gonçalves PC. Manual para diagnóstico das helmintoses de ruminantes. Tokyo: Japan International Cooperation Agency; 1998.

van Wyk JA, Mayhew E. Morphological identification of parasitic nematode infective larvae of small ruminants and cattle: A practical lab guide. Onderstepoort J Vet Res 2013; 80(1): 539. http://dx.doi.org/10.4102/ojvr.v80i1.539. PMid:23718204. 
Vasconcelos THC, Modesto-Filho J, Diniz MFFM, Santos HB, Aguiar FB, Moreira PVL. Estudo toxicológico pré-clínico agudo com o extrato hidroalcoólico das folhas de Cissus sicyoides L. (Vitaceae). Rev bras farmacogn 2007;17(4): 583-591.

Ways TM, Lau WM, Khutoryanskiy VV. Chitosan and its derivatives for application in mucoadhesive drug delivery systems. Polymers 2018; 10(267): 1-37. http://dx.doi.org/10.3390/polym10030267. PMid:30966302.

Zhao Y, Wang C, Chow AHL, Ren K, Gong T, Zhang Z, et al. Self-Nanoemulsifying Drug Delivery System (SNEDDS) for oral delivery of Zedoary essential oil: formulation and bioavailability studies. Int J Pharm 2010; 383(1-2): 170-177. http://dx.doi.org/10.1016/j.ijpharm.2009.08.035. PMid:19732813.

Zhu L, Dai J, Yang L, Qiu J. Anthelmintic activity of Arisaema franchetianum and Arisaema lobatum essential oils against Haemonchus contortus. J Ethnopharmacol 2013; 148(1): 311-316. http://dx.doi.org/10.1016/j.jep.2013.04.034. PMid:23624115.

\section{Supplementary Material}

Supplementary material accompanies this paper.

Figure S1. Chromatograms of carvacryl acetate obtained by gas chromatography coupled with mass spectrometry. A. The detection of compounds at retention times of 20,472 - carvacrol (0.55\%) and 22,799 - carvacryl acetate (99.45\%); B. and C. mass spectra corresponding to carvacrol and carvacryl acetate, respectively.

This material is available as part of the online article from http://www.scielo.br/rbpv 


\title{
Erratum
}

In the article "Anthelmintic activity of nanoencapsulated carvacryl acetate against gastrointestinal nematodes of sheep and its toxicity in rodents", DOI number https://doi.org/10.1590/s1984-29612019098, published in Brazilian Journal of Veterinary Parasitology, volume 29, issue 1, 2020, e013119, which reads in the affiliation:

\author{
Weibson Paz Pinheiro André \\ José Ribamar de Paiva Junior ${ }^{2}$ \\ Géssica Soares Cavalcante ${ }^{1,3}$ \\ Wesley Lyeverton Correia Ribeiro ${ }^{4}$ \\ José Vilemar de Araújo Filho' \\ Jéssica Maria Leite dos Santos ${ }^{1}$ \\ Ana Paula Negreiros Nunes Alves ${ }^{5}$ \\ Jomar Patrício Monteiro ${ }^{6}$ \\ Selene Maia de Morais ${ }^{3}$ \\ Isaac Neto Goes da Silva ${ }^{7}$ \\ Lorena Mayana Beserra de Oliveira' \\ Flávia Oliveira Monteiro da Silva Abreu² \\ Claudia Maria Leal Bevilaqua1*
}

'Laboratório de Doenças Parasitárias, Programa de Pós-graduação em Ciências Veterinárias, Universidade Estadual do Ceará - UECE, Fortaleza, CE, Brasil

2Laboratório de Química Analítica e Ambiental, Programa de Pós-graduação em Ciências Naturais, Universidade Estadual do Ceará - UECE, Fortaleza, CE, Brasil

${ }^{3}$ Laboratório de Química de Produtos Naturais, Programa de Pós-graduação em Ciências Veterinárias, Universidade Estadual do Ceará - UECE, Fortaleza, CE, Brasil

${ }^{4}$ Departamento de Fisiologia e Farmacologia, Faculdade de Medicina, Universidade Federal do Ceará - UFC, Fortaleza, CE, Brasil

${ }^{5}$ Faculdade de Farmácia, Odontologia e Enfermagem, Universidade Federal do Ceará - UFC, Fortaleza, CE, Brasil ${ }^{6}$ Embrapa Caprinos e Ovinos, Sobral, CE, Brasil

${ }^{7}$ Laboratório de Patologia Clínica, Faculdade de Veterinária, Universidade Estadual do Ceará - UECE, Fortaleza, CE, Brasil

It should be read:

Weibson Paz Pinheiro André

José Ribamar de Paiva Junior ${ }^{2}$

Géssica Soares Cavalcante ${ }^{1,3}$

Wesley Lyeverton Correia Ribeiro ${ }^{4}$

José Vilemar de Araújo Filho ${ }^{1}$

Jéssica Maria Leite dos Santos ${ }^{5}$

Ana Paula Negreiros Nunes Alves ${ }^{6}$

Jomar Patrício Monteiro ${ }^{7}$ 
Selene Maia de Morais ${ }^{3}$

Isaac Neto Goes da Silva ${ }^{8}$

Lorena Mayana Beserra de Oliveira ${ }^{1}$

Flávia Oliveira Monteiro da Silva Abreu²

Claudia Maria Leal Bevilaqua1*

'Laboratório de Doenças Parasitárias, Programa de Pós-graduação em Ciências Veterinárias, Universidade Estadual do Ceará - UECE, Fortaleza, CE, Brasil

2Laboratório de Química Analítica e Ambiental, Programa de Pós-graduação em Ciências Naturais, Universidade Estadual do Ceará - UECE, Fortaleza, CE, Brasil

${ }^{3}$ Laboratório de Química de Produtos Naturais, Programa de Pós-graduação em Ciências Veterinárias, Universidade Estadual do Ceará - UECE, Fortaleza, CE, Brasil

${ }^{4}$ Departamento de Fisiologia e Farmacologia, Faculdade de Medicina, Universidade Federal do Ceará - UFC, Fortaleza, CE, Brasil

${ }^{5}$ Centro Universitário INTA - UNINTA, Sobral, CE, Brasil

${ }^{6}$ Faculdade de Farmácia, Odontologia e Enfermagem, Universidade Federal do Ceará - UFC, Fortaleza, CE, Brasil

${ }^{7}$ Embrapa Caprinos e Ovinos, Sobral, CE, Brasil

${ }^{8}$ Laboratório de Patologia Clínica, Faculdade de Veterinária, Universidade Estadual do Ceará - UECE, Fortaleza, CE, Brasil 